\title{
Jan Charytański SJ, Czesława Margarita Sondej OSU, Kim jestem jako człowiek i chrześcijanin. Rozważania w oparciu o Katechizm Kościota Katolickiego, WAM, Kraków 2006, ss. 216.
}

Czym różni się kapłan naukowiec od „zwykłego” człowieka nauki? Przede wszystkim tym, że nie tylko „posiadł wiedzę”, ale przede wszystkim nadal pozostał kapłanem. I jak każdy kapłan powtarza za św. Pawłem: „Nie jest dla mnie powodem do chluby to, że głoszę Ewangelię. Świadom jestem ciążącego na mnie obowiązku. Biada mi, gdybym nie głosił Ewangelii!” (1 Kor 9, 16). Owo głoszenie Dobrej Nowiny integralnie „zawiera się” w kapłaństwie i choć życie wyznacza kapłanom różne role, nigdy nie wychodzą z tej, którą powierzył im sam Chrystus: „Idźcie na cały świat i głoście Ewangelię wszelkiemu stworzeniu!” (Mk 16, 15).

Te nieszczególnie oryginalne rozważania o zadaniach kapłana niniejszą recenzję otwierają nieprzypadkowo. W szczególny sposób bowiem zdaje z nich sobie sprawę ks. prof. Jan Charytański SJ, który we współpracy z s. prof. Czesławą Margaritą Sondej OSU opublikował właśnie tom rozważań przygotowanych na podstawie Katechizmu Kościoła Katolickiego pod znamiennym tytułem Kim jestem jako człowiek i chrześcijanin.

Kiedy w 1994 roku ogłoszona została polska wersja Katechizmu Kościoła Katolickiego, ukazywały się liczne publikacje na jego temat: recenzowano go, komentowano, dokonywano jego interpretacji, publikowano zbiory kazań inspirowane zawartymi w nim treściami. Dziś, po 12 latach, Katechizm został nieco zapomniany, a przecież zawarte w nim treści są niemniej aktualne. Co więcej, wyzwania, jakie stawia przed człowiekiem współczesny świat, jeszcze bardziej rodzą potrzebę ciągłej «egzegezy» treści katechizmu. Ks. prof. Jan Charytański we wstępie do książki trafnie te wyzwania identyfikuje. Łaknienie postępu, sukcesu, korzystanie z przyjemności życia i wszystkie te zjawiska, jakie zrodziła kultura postmodernizmu, laicyzacja życia, spychanie wiary i religii do sfery prywatnej życia ludzkiego i negowanie możliwości jej wpływu na życie publiczne, globalizacja i wszystkie inne przejawy nowej ideologii stoją - jak podkreśla Autor - w sprzeczności z chrześcijaństwem i jego moralnością. Człowiek, mimo iż znajduje się w centrum uwagi, to jednak w tym wszystkim się gubi. I staje z pustymi rękami przed powracającymi zawsze i wciąż metafizycznymi pytaniami o istotę swego człowieczeństwa. Kim jestem? - zadaje sobie pytanie i dość często nie potrafi znaleźć na nie odpowiedzi. W jej poszukiwaniu z pewnością pomogą mu rozważania ks. Jana Charytańskiego i s. Czesławy Margarity Sondej.

Autorzy prowadzą czytelnika krok po kroku. Jasny i klarowny układ pozwala czytać teksty pomieszczone w książce Kim jestem jako czlowiek i chrześcijanin razem z Katechizmem Kościoła Katolickiego. Punkt po punkcie znajdziemy w prezentowanej publikacji refleksje odwołujące nas do niemal wszystkich z blisko trzech tysięcy punktów, jakie znajdują się w Katechizmie. A to wszystko po to, aby udzielić odpowiedzi na ontologiczne pytanie: „Kim jestem jako człowiek i jako chrześcijanin?” Autorzy nie dają jej jednak pojedynczemu czytelnikowi wprost. Nie odpowiadają, ale pomagają 
szukać odpowiedzi, prowadząc owo poszukiwanie w trzech zasadniczych obszarach. Są to: prawdziwa wielkość człowieka, człowiek dotknięty grzechem i powołany do stałej walki ze złem, człowiek istotą społeczną i powołany do tworzenia wspólnego dobra. Tak więc przez cały czas w centrum pozostaje człowiek, choć autorzy podkreślają że nie jest on centrum świata decydującym o wszystkim, bowiem prawdziwe centrum świata stanowi Bóg, a człowiek jest tylko jednym ze stworzeń całkowicie od Boga zależnym. Dlatego: „,iedny jest człowiek, który upatruje źródło swej wielkości i godności w samym sobie, wyczerpuje swe siły i możliwości zapewnienia sobie w ciągu tych kilkudziesięciu lat powodzenia $\mathrm{w}$ życiu gospodarczym czy politycznym z zapomnieniem o innych wartościach. Nie chce myśleć o śmierci, która przerwie wszystko i strąci go w nicość" (s. 209).

Po książkę może sięgnąć każdy. I choć autorzy na zakończenie przepraszają czytelników, że mogli natrafić na miejsca trudne i niejasne, mało zrozumiałe, to ich obawy są zupełnie zbyteczne. Przy w pełni profesjonalnym podejściu do zagadnienia, wymagającym niezwykle wnikliwej wiedzy i znajomości omawianych treści, w stylu rozważań nie ma ani krzty nadmiernej intelektualizacji wypowiedzi, tak charakterystycznej dla wielu współczesnych prac naukowych. Po książkę mogą sięgnąć zarówno osoby zgłębiające wiedzę naukową z zakresu teologii i pedagogiki - pracownicy naukowi oraz studenci, kapłani poszukujący inspiracji dla swoich kazań, ludzie pragnący pogłębiać swoją wiarę, jak i wszyscy ci, którzy szukali, szukają czy będą szukać odpowiedzi na nurtujące ich podstawowe metafizyczne pytania. Każdy czytelnik zrozumie zawarte w tej książce treści i każdy będzie mógł znaleźć w niej znaleźć coś ważnego dla siebie.

Lektura książki ks. Jana Charytańskiego i s. Czesławy Margarity Sondej może być osobliwym doświadczeniem. Jeśli czytelnik podejdzie do niej z naukowym zacięciem - znajdzie w niej interesującą egzegezę treści Katechizmu, jeśli z filozoficznym zagubieniem - pomoże mu ona odnaleźć siebie, a jeśli przeczyta ją z otwartym sercem - doświadczy jednych z najlepszych w swoim życiu rekolekcji. I to nie tylko takich, po których pozostaną jedynie wspomnienia, bowiem dzięki ich zmaterializowaniu w formie książkowej będzie można do nich wielokrotnie powracać.

I jeszcze jedno. Autorzy - co wyraźnie wynika z treści książki i zostało wyrażone wprost - zaadresowali swoją książkę do współczesnego człowieka, takiego, który próbuje odnaleźć siebie jako człowieka i chrześcijanina na progu XXI wieku. Takie jasne «zaprojektowanie» odbiorcy czyni go «żywym», zbliża do autorów tworzy wspólnotę tych, którzy tę książkę napisali, czytali, czytają lub będą czytać, będą ją przeżywać i doświadczać jej obecności w swoim życiu. Teraz i w przyszłości, bo z całą pewnością książka ta nigdy się nie zdezaktualizuje.

Adam Solak*

* Ks. dr hab. Adam Solak, prof. UKSW, jest pracownikiem naukowym Uniwersytetu Kardynała Stefana Wyszyńskiego w Warszawie i Wyższej Szkoły Filozoficzno-Pedagogicznej „Ignatianum” w Krakowie. 